\title{
Cis-5-Olefinic Nonmethylene-Interrupted Fatty Acids in Lipids of Seeds, Arils and Leaves of Japanese Yew
}

\author{
Yutaka ITABASHI and Toru TAKAGI \\ Department of Chemistry, Faculty of Fisheries, Hokkaido \\ University (Minato-cho, Hakodate)
}

\begin{abstract}
Fatty acids from the lipids of the Japanese yew Taxus cuspidata seeds collected at various districts all contained rich amounts of cis-5, cis-9-octadecadienoic acid (5,9-18:2) (16.1 18.9\%) with small amounts of 5,9,12-18:3(1.8 3.4\%) and 5,11,14-20:3(1.0 2.8\%) as cis-5-olefinic nonmethyleneinterrupted (NMI) acids. On the other hand, fatty acids from the neutral lipids of the arils and leaves contained appreciable amounts of 5,11,14-20:3 (leaves $8.1 \%$ and arils $1.2 \%$ ) and 5,11,14,17-20:4 (leaves $6.2 \%$ and arils $1.5 \%$ ), but 5,9-18:2 was not detected or detected only in a trace amount in them. Fatty acids from the galactolipids of the leaves also contained small amounts of the NMI acids $(5,9,12,15-18: 4 \quad 0.3 \%, 5,11,14-20: 3 \quad 0.4 \%, 5,11,14,17-20: 41.8 \%)$, in addition to a large amount of linolenic acid (72.8\%). The 5-olefinic NMI acids were generally more rich in neutral lipids than in polar lipids. The yew seeds showed nearly the same fatty acid composition during maturation.
\end{abstract}

\section{Introduction}

The occurrence of unusual monoenoic and nonmethylene-interrupted (NMI) polyenoic fatty acids with a $5: 6$ double bond has been found in the plants belonging to some families ${ }^{1}$. Taxaceae is one of them, and the NMI poly= enoic acids have been found in the tissues of two species of it, the seeds ${ }^{2)}$ and leaves ${ }^{3)}$ of the yew Taxus baccata collected in $\mathrm{USA}^{2)}$ and Scotland $^{3)}$, and the seeds of Torreya nucifera collected in Japan ${ }^{4}$ and Korea ${ }^{5)}$. The fatty acids from $T$. baccata seed oil contained a noticeable amount of cis-5, cis-9-octadecadienoic acid $(5,9-18: 2)$ with small amounts of 5,11$20: 2$ and $5,11,14-20: 3^{2)}$. On the other hand, the fatty acids from $T$. baccata leaf lipids mainly contained 5,11,14-20:3 and 5, $11,14,17-20: 4$ as the NMI acids ${ }^{3}$. T. nucifera seed oil contained only one NMI acid, 5, 11, 14 $-20: 3^{4), 5)}$.

The present work reports the compositions of the fatty acids from the lipids in the seeds, arils and leaves of the Japanese yew Taxus cuspidata.

\section{Experimental}

\subsection{Extraction, Fractionation and}

\section{Methanolysis of Lipids}

Fruits collected from yew trees were immedi= ately separated to seeds and arils, and lipids were extracted by the method of Bligh and Dyer $^{6)}$ after several days. Total lipids were separated to neutral and polar lipids by column chromatography using silicic acid (Silica Gel 60, Merck) and chloroform, acetone and methanol for development. Lipids were converted to methyl esters by transesterification with $2 \%$ sodium methoxide in methanol by refluxing for $20 \mathrm{~min}$.

\subsection{Chromatography}

Gas-liquid chromatography (GLC) of methyl esters was carried out with glass capillary col= umns (60 or $70 \mathrm{~m} \times 0.28 \mathrm{~mm}$ i.d.) coated with Silar $5 \mathrm{CP}^{7)}$. The carrier gas was nitrogen at 1 or $0.4 \mathrm{ml} / \mathrm{min}$. The splitting ratio was $1 / 25$ or $1 / 200$. The column temperature was 170 or $190^{\circ} \mathrm{C}$ isothermally. The detector (FID) and in jector temperatures were maintained at $230^{\circ} \mathrm{C}$.

Thin-layer chromatography (TLC) of methyl esters was carried out on 15\% silver nitrate impregnated silicic acid (Silica Gel G, Merck) plates $(20 \times 20 \mathrm{~cm}, 0.5 \mathrm{~mm}$ thick $)$ using ethyl acetate-hexane $(19: 1 \mathrm{vol} / \mathrm{vol})$ for development. Bands were located under UV after spraying with $2^{\prime}, 7^{\prime}$-dichlorofluorescein ethanol solution 
and were recovered by extraction with ether.

\subsection{Reductive Ozonolysis}

Reductive ozonolysis was carried out by the ordinary method using triphenylphosphine ${ }^{8)}$. One $\mathrm{ml}$ of a dichloromethane solution containing $10 \mathrm{mg}$ methyl esters was cooled in acetone-dry ice bath and ozone-air mixture was bubbled through at $30 \mathrm{ml} / \mathrm{min}$. After bubbling for a few minutes, a few crystals of triphenylphos= phine was added to the solution, and the reac= tion products were analyzed by GLC. The GLC columns were glass tubes $(1.5 \mathrm{~m} \times 3 \mathrm{~mm}$ i.d.) packed with $5 \%$ Silar $10 \mathrm{C}$ on $100 \sim 120$ mesh Gas Chrom Q. The column temperature was programmed from 80 to $270^{\circ} \mathrm{C}$ at $2^{\circ} \mathrm{C} / \mathrm{min}$. The detector (FID) and injector temperatures were maintained at $300^{\circ} \mathrm{C}$. The carrier gas was nitrogen at $40 \mathrm{ml} / \mathrm{min}$.

2.4 Nuclear Magnetic Resonance (NMR)

A JEOL FX-200 spectrometer (Nippon Den= shi Co., Tokyo) in Fourier transform mode at 199.50 MHz for ${ }^{1} \mathrm{H}-\mathrm{NMR}$ and $25.00 \mathrm{MHz}$ for ${ }^{13} \mathrm{C}-\mathrm{NMR}$ was used to obtain NMR spectra of methyl esters in deuterochloroform.

\subsection{Mass Spectra (MS)}

MS of the pyrrolidides of unsaturated fatty acids were taken for determination of the double bond positions with a JEOL mass spectrometer JMS-D 300 operated at an ionization potential $70 \mathrm{eV}$ and ion source temperature $170^{\circ} \mathrm{C}$.

Fatty acid pyrrolidides were prepared on a microscale ${ }^{9}$. Methyl esters $(10 \mathrm{mg}$ ) were dis= solved in freshly distilled pyrrolidine $(1 \mathrm{ml})$ and acetic acid $(0.1 \mathrm{ml})$. The mixture was kept at $100^{\circ} \mathrm{C}$ in a screw-cap centrifuge tube for $30 \mathrm{~min}$ under nitrogen. After addition of water $(3 \mathrm{ml})$, the products were extracted twice with dichlos romethane (each $3 \mathrm{ml}$ ). The solution was washed with dilute hydrochloric acid, and then with water until neutral. After drying over anhydrous magnesium sulfate, the solvent was removed by nitrogen jet. Conversion to pyr= rolidides was checked by GLC using glass col= umns ( $1.5 \mathrm{~m} \times 3 \mathrm{~mm}$ i.d.) packed with $3 \%$ Silar $10 \mathrm{C}$ on $100 \sim 120$ mesh Gas Chrom Q. The column temperature was programmed from 60 to $260^{\circ} \mathrm{C}$ at $2^{\circ} \mathrm{C} / \mathrm{min}$.

\subsection{Partial Hydrogenation with Hydra $=$ zine}

Partial hydrogenation of unsaturated fatty acids was carried out according to the method described previously ${ }^{10)}$. A mixture of $10 \mathrm{ml}$ of $10 \%$ ( $\mathrm{vol} / \mathrm{vol}$ ) hydrazine hydrate in methanol and $10 \mathrm{mg}$ fatty acids was stirred in air at $50^{\circ} \mathrm{C}$ for $30 \mathrm{~min}$ by a magnetic stirrer. The products were extracted with hexane and converted to methyl esters with $7 \%$ boron trifluoride in methanol by refluxing for $30 \mathrm{~min}$. Methyl esters were analyzed by the GLC using glass capillary columns under the conditions described in $2 \cdot 2$.

\section{Results and Discussion}

\subsection{Unusual Fatty Acids}

In GLC of the methyl esters from the lipids of seeds, arils and leaves of T. cuspidata, 26 peaks have been observed on the chromatograms (Fig.-1). In them, 20 peaks were identified

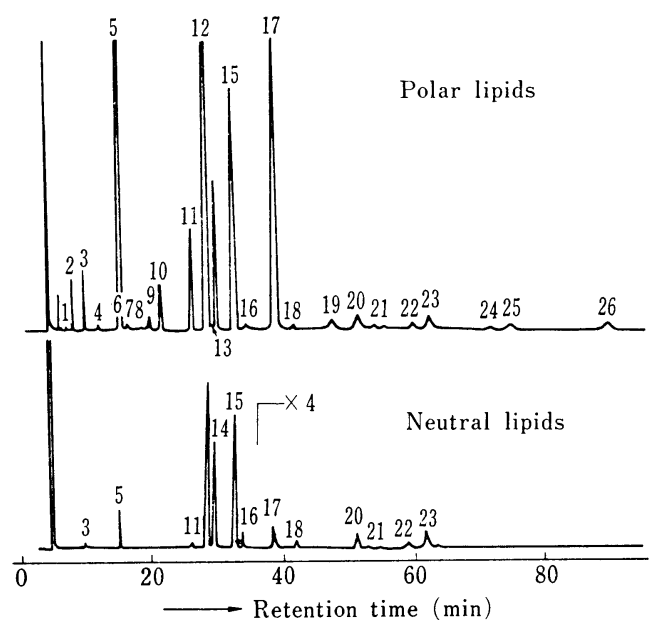

(1) 12:0; (2) 13:0; (3) 14:0; (4) 15:0; (5) 16:0; (6) 16:1(n-9); (7) $16: 1(n-7) ;(8) 16: 2(n-6) ;(9) 17: 0 ;(10) 16: 3(n-3) ;(11)$ 18:0; (12) 18:1(n-9); (13) 18:1( $n-7) ;(14) 18: 2(5,9) ;(15) 18: 2$ $(n-6) ;(16) 18: 3(5,9,12) ;(17) 18: 3(n-3) ;(18) 18: 4(5,9,12,15)$; (19) $20: 0 ;(20) 20: 1(n-9) ;(21) 20: 2(5,11) ;(22) 20: 2(n-6) ;(23)$ $20: 3(5,11,14) ;(24) 20: 3(n-3) ;(25) 20: 4(5,11,14,17) ;(26) 22: 0$

Fig.-1 Gas chromatograms of methyl esters of fatty acids from Japanese yew $T$. cuspidata seed lipids on a glass capil= lary column coated with Silar $5 \mathrm{CP}$.

as fatty acids having usual structures by com= parison of the retention times with reference specimens ${ }^{7)}$, but 6 peaks (peaks 14, 16, 18, 21, 23 and 25) showed unusual retention data.

\section{$3 \cdot 2$ Identification of NMI acids}

GLC peaks 21,23 and 25 were identified as $5,11-20: 2,5,11,14-20: 3$ and $5,11,14,17$ - 
$20: 4$, respectively, by the agree= ment of their retention data with those of the reference speciments obtained from the lipids of sea urchins $^{11}$, Podocarpus nagi seeds $^{10}$ ) and Cedrus deodra seeds ${ }^{12}$. GLC peak 18 was tentatively identified as $5,9,12,15-18: 4$ from the re= tention data of NMI and usual fatty acid methyl esters ${ }^{12)}$.

On argentation TLC plates, $R_{f}$ values of the methyl esters from

$T$. cuspidata lipids decreased in the following order : 9-18:1 and 11-20:1, 9, 12-18:2 and $11,14-20: 2$, GLC peaks 14 and 21 (I ), 9, $12,15-18: 3$, GLC peaks 16 and 23 (II), and GLC peaks 18 and 25. By the TLC, the com $=$ ponent of GLC peak 14 (TLC fraction I) was isolated from the neutral lipids of the seeds in purity of more than $96 \%$. GLC of the ozonolysis products of this component showed the peaks of $\mathrm{C}_{5}$ aldehydic-acid ester (28.2\%), $\mathrm{C}_{9}$ aldehyde $(60.6 \%)$ and $\mathrm{C}_{4}$ dialdehyde (11.2\%). These products indicate double bonds in positions 5 and 9.

$\mathrm{CH}_{3}\left(\mathrm{CH}_{2}\right)_{7} \mathrm{CH}=\mathrm{CH}\left(\mathrm{CH}_{2}\right)_{2} \mathrm{CH}=\mathrm{CH}\left(\mathrm{CH}_{2}\right)_{3} \mathrm{COOCH}_{3}$ $\mathrm{C}_{9}$ $\mathrm{C}_{4}$ $\mathrm{C}_{5}$

aldehyde dialdehyde aldehydic acid ester

GLC of the ozonolysis products of TLC fraction II from the neutral lipids of the seeds showed $\mathrm{C}_{5}$ aldehydic-acid ester (26.0\%), $\mathrm{C}_{9}$ aldehydic acid ester (16.0\%), $\mathrm{C}_{6}$ aldehyde (57.1 \%) and a trace amount of $\mathrm{C}_{4}$ dialdehyde. These products indicate double bonds in positions 5,9 , and 12. The $\mathrm{C}_{9}$ aldehydic acid ester was pros duced from $9,12,15-18: 3$ contaminated in this fraction.

$$
\begin{array}{cc}
\mathrm{CH}_{3}\left(\mathrm{CH}_{2}\right)_{4} \mathrm{CH}=\mathrm{CHCH}_{2} \mathrm{CH}=\mathrm{CH}\left(\mathrm{CH}_{2}\right)_{2} \mathrm{CH}= \\
\mathrm{C}_{6} & \mathrm{C}_{4} \\
\text { aldehyde } & \text { dialdehyde } \\
& \mathrm{CH}\left(\mathrm{CH}_{2}\right)_{3} \mathrm{COOCH}_{3} \\
& \mathrm{C}_{5} \\
& \text { aldehydic acid ester }
\end{array}
$$

The retention data of GLC peak 16 were in agreement with those of 5,9,12-18:3 obtained from Pinus koraiensis ${ }^{12}$.

Reference speciments for the GLC identifi= cation of the ozonolysis products were prepared by the ozonolysis of methyl ester of $5,11,14-$ $20: 3$ from $P$. nagi seed lipids ${ }^{10)}$ for $\mathrm{C}_{5}$ aldehydic acid ester, 1,5-cyclooctadiene for $\mathrm{C}_{4}$ dialdehyde and methyl oleate for $\mathrm{C}_{9}$ aldehydic -acid ester. Reagent grade aldehydes $\left(\mathrm{C}_{6}\right.$ and $\mathrm{C}_{9}$ ) were also used for the identification.

MS of the pyrrolidide derivative of GLC peak 14 is shown in Fig.-2. The irregular ion fragments for each carbon atom were as follows: $\mathrm{C}_{4}(m / e) 140$, intensity $0.8 \%$ to parent fragment) $-\mathrm{C}_{5}(m / e 152,0.4 \%)$ and $\mathrm{C}_{8}(m / e$ 194, 0.5\%) $-\mathrm{C}_{9}(m / e 206,0.3 \%)$. The molecular ion frag= ment appeared at $m / e 333(4.8 \%)$. These fragments indicate the 5,9-18:2 structure for GLC peak 14 .

IR and UV spectra of each TLC fraction showed no absorptions of trans and conjugated double bonds, respectively. ${ }^{1} \mathrm{H}$ and ${ }^{13} \mathrm{C}-\mathrm{NMR}$ spectra of GLC peak 14 are shown in Fig.-3. The carbon chemical shifts (ppm) are as follows:

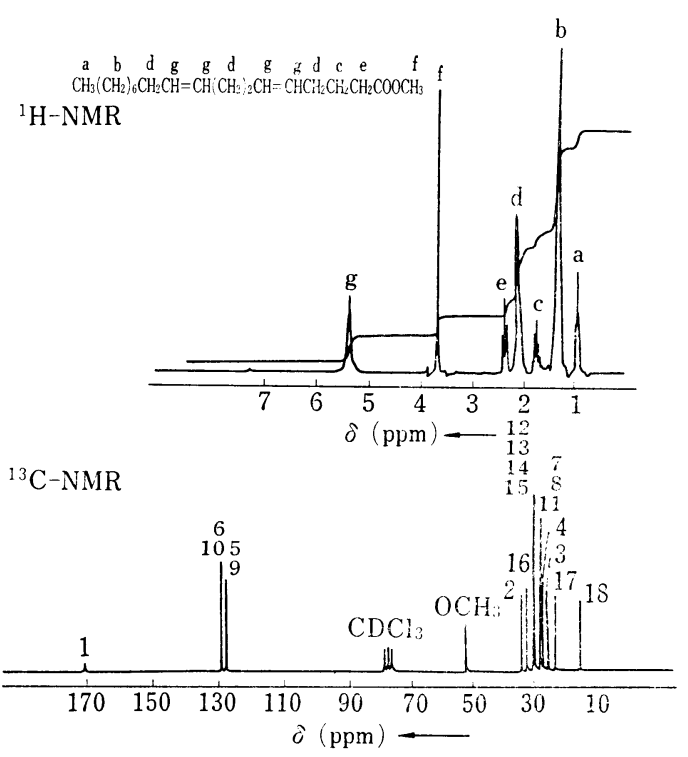

Figures in ${ }^{13} \mathrm{C}$-NMR spectrum indicate the locant of carbon atoms.

Fig.-3 NMR spectra of GLC peak $14(5,9-18: 2)$ 


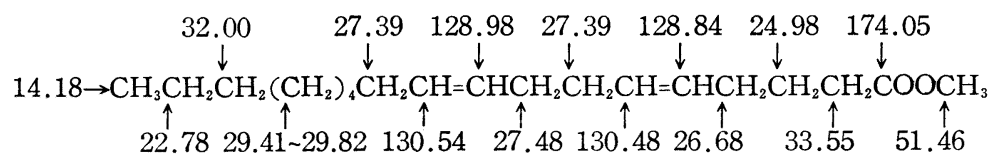

The presence of $5: 6$ double bond is indicated by the difference in chemical shifts for two allylic carbon atoms. The differential shifts of monoenoic acids were 4.30 for $4: 5,0.70$ for $5: 6,0.40$ for $6: 7,0.25$ for $7: 8$, and 0.10 for $8: 9$ and $9: 10^{13}$. Therefore, the difference 0.71 of the chemical shifts 27.39 and 26.68 in our spectrum indicates that the first double bond is in the position 5 . The chemical shift $32.00\left(\mathrm{C}_{16}\right)$ means that a second double bond is in the positions 8,9 , or $10^{13}$. The ${ }^{1} \mathrm{H}-\mathrm{NMR}$ spectrum (Fig. -3) had no absorptions at 2.77 $2.81 \mathrm{ppm}$ for the $\mathrm{CH}_{2}$ hydrogen of $=\mathrm{CHCH}_{2}$ $\mathrm{CH}=$. The absorptions at $5.35 \sim 5.37 \mathrm{ppm}$ (in= tensity $4 \mathrm{H}$ ) show the $\mathrm{CH}$ hydrogen of $-\mathrm{CH}=$ $\mathrm{CH}-$. These results support the 5,9-18:2 structure for GLC peak 14.

GLC of the partial hydrogenation products of GLC peak 14 showed the following composition : $18: 0$ 15.4\%, 5-18:28.9\%, 9-18: $120.1 \%$ and GLC peak $1435.6 \%$. Complete separation was obtained between 5- and 9-18:1 peaks.

Table-1 Fatty acid composition of yew lipids*

\begin{tabular}{|c|c|c|c|c|c|c|c|c|c|c|}
\hline \multirow{4}{*}{$\begin{array}{l}\text { Place } \\
\text { Date } \\
\text { Part } \\
\text { Lipid class } \\
\end{array}$} & \multirow{4}{*}{$\begin{array}{c}\text { Sapporo } \\
\text { Sep. } 18 \\
1979 \\
\text { Seed } \\
\text { T }\end{array}$} & \multirow{4}{*}{$\begin{array}{l}\text { Nanae } \\
\text { Oct. } 18 \\
1979 \\
\text { Seed } \\
\text { T }\end{array}$} & \multirow{4}{*}{$\begin{array}{c}\text { Hiroshi= } \\
\text { ma } \\
\text { Oct. } 6 \\
1980 \\
\text { Seed } \\
\text { T }\end{array}$} & \multicolumn{7}{|c|}{ Hakodate } \\
\hline & & & & \multirow{2}{*}{\multicolumn{4}{|c|}{$\begin{array}{c}\text { Oct. 25 } \\
1978 \\
\end{array}$}} & \multirow{2}{*}{\multicolumn{3}{|c|}{$\begin{array}{l}\text { Oct. } \\
1980 \\
\text { Leaf }\end{array}$}} \\
\hline & & & & & & \multicolumn{2}{|c|}{ Aril } & & \\
\hline & & & & $\mathrm{N}$ & $\mathrm{P}$ & $\mathrm{N}$ & $\mathrm{P}$ & $\mathrm{N}$ & G & $\mathrm{P}$ \\
\hline Lipid\% & - & 20.8 & 15.5 & 16.3 & 1.69 & 0.21 & 0.22 & 0.95 & 1.48 & 0.76 \\
\hline $12: 0$ & - & - & - & - & 0.04 & 0.02 & 0.05 & - & Tr. & Tr. \\
\hline $13: 0$ & - & - & - & - & 0.54 & - & - & - & - & Tr. \\
\hline $14: 0$ & 0.09 & 0.06 & 0.10 & - & 0.70 & 4.37 & 2.06 & 3.16 & 0.35 & Tr. \\
\hline $15: 0$ & - & - & - & - & 0.07 & 0.23 & 0.24 & 0.38 & - & Tr. \\
\hline $16: 0$ & 3.07 & 2.99 & 3.40 & 2.65 & 22.82 & 15.93 & 30.45 & 8.59 & 2.87 & 30.62 \\
\hline $16: 1 n-9$ & 0.04 & - & 0.08 & $\operatorname{Tr}$. & 0.14 & 0.27 & 0.12 & 0.49 & 0.11 & $\operatorname{Tr}$. \\
\hline$n-7$ & 0.08 & 0.06 & 0.07 & 0.04 & 0.07 & 1.08 & 0.75 & 0.22 & 0.15 & Tr. \\
\hline $16: 2 n-6$ & Tr. & Tr. & - & Tr. & 0.07 & $\operatorname{Tr}$. & 0.24 & Tr. & 0.79 & 0.17 \\
\hline $17: 0$ & Tr. & Tr. & 0.04 & Tr. & 0.38 & Tr. & 0.20 & $\operatorname{Tr}$. & $\operatorname{Tr}$. & 0.40 \\
\hline $16: 3 n-3$ & Tr. & Tr. & - & Tr. & 1.23 & 0.54 & 0.67 & 1.61 & 11.67 & 0.56 \\
\hline $18: 0$ & 1.16 & 1.40 & 1.42 & 0.80 & 3.98 & 1.40 & 1.72 & 1.19 & 0.18 & 1.17 \\
\hline $18: 1 n-9$ & 37.85 & 35.26 & 48.34 & 37.10 & 31.17 & 15.52 & 6.79 & 17.72 & 1.52 & 6.54 \\
\hline$n-7$ & 0.25 & 0.27 & 0.07 & - & - & 0.23 & 1.38 & Tr. & Tr. & 0.28 \\
\hline $18: 25,9$ & 18.47 & 18.93 & 17.89 & 16.06 & 5.26 & - & - & Tr. & Tr. & - \\
\hline$n-6$ & 30.42 & 32.45 & 23.32 & 32.96 & 10.15 & 28.10 & 21.83 & 14.36 & 4.67 & 8.07 \\
\hline $18: 35,9,12$ & 2.83 & 2.94 & 1.75 & 3.37 & 0.30 & 0.13 & 0.13 & $\operatorname{Tr}$. & Tr. & - \\
\hline$n-3$ & 1.46 & 1.33 & 1.07 & 1.58 & 17.43 & 28.56 & 27.05 & 31.18 & 72.83 & 48.56 \\
\hline $18: 45,9,12,15$ & 0.16 & 0.16 & 0.08 & 0.24 & Tr. & 0.18 & - & 0.80 & 0.29 & - \\
\hline $20: 0$ & Tr. & Tr. & $\operatorname{Tr}$. & Tr. & 0.66 & 0.38 & 1.26 & 1.66 & 1.19 & Tr. \\
\hline $20: 1 n-9$ & 1.55 & 1.47 & 0.97 & 1.44 & 1.00 & 0.37 & 1.41 & 1.29 & 0.38 & $\operatorname{Tr}$. \\
\hline $20: 25,11$ & $\operatorname{Tr}$. & 0.16 & 0.08 & Tr. & 0.38 & Tr. & - & 1.13 & $\operatorname{Tr}$. & $\operatorname{Tr}$. \\
\hline$n-6$ & 0.61 & 0.72 & 0.34 & 0.95 & 0.65 & - & - & - & - & - \\
\hline $20: 35,11,14$ & 1.96 & 1.80 & 0.98 & 2.81 & 1.42 & 1.18 & 0.68 & 8.10 & 0.36 & 1.89 \\
\hline $20: 45,11,14,17$ & - & - & - & - & 0.54 & 1.51 & 1.28 & 6.24 & 1.79 & 1.74 \\
\hline $22: 0$ & - & - & - & - & 1.00 & - & 1.68 & 1.88 & 0.88 & - \\
\hline
\end{tabular}

$* \mathrm{~T}$; Total lipids, $\mathrm{N}:$ Neutral lipids, $\mathrm{P}:$ Polar lipids, and $\mathrm{G}:$ Galactolipids. Yields were obtained without drying of the seeds. Nanae is in the suburbs of Hakodate. A trace amount of $20: 3 n-3$ was detected additionally. 
The peaks were identified by mixed injection with a reference specimen containing 5-18:1 from sea urchin lipids ${ }^{11}$. These results also give an evidence for the 5,9-18:2 structure.

\subsection{Fatty Acid Composition}

The fatty acid composition of the lipids from the seeds, arils and leaves of the Japanese yew T. cuspidata are shown in Table-1. The fatty acid composition of the seeds collected at the different places in northern Japan resembled one another. The content of 5,9-18:2 in the seed lipids $(16.1 \sim 18.9 \%)$ was significantly higher than that of the American yew $T$. baccata seed lipids $(12.2 \%)^{2)}$. The 5, 9-18: 2 was also rich in the seeds collected at Hiro= shima in southern Japan. This NMI acid, how $=$ ever, was not detected or detected in a trace amount from the aril and leaf lipids (Table-1). $T$. cuspidata is one of the most popular garden trees in northern Japan and its seeds are easily available in fairly large amounts. T. cuspidata seed lipids, therefore, are a favorable source for preparation of 5, 9-18:2.

The 5-olefinic $\mathrm{C}_{18}$ NMI acids found in $T$. cuspidata lipids seem to be formed from usual unsaturated acyl moieties by the 5 -desaturase as follows :

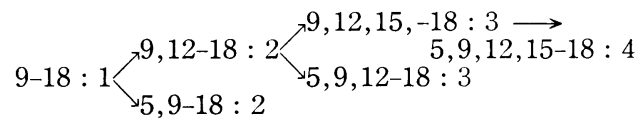

The conversion to $5,9-18: 2$ from 9-18:1 occurs exclusively in the seeds. The 5-olefinic $\mathrm{C}_{20}$ NMI acids are more rich in the arils and leaves than in the seeds (Table-1). Therefore, the 5-desaturase in the arils and leaves seems to selectively dehydrogenate $11,14-20: 2$ and $11,14,17-20: 3$ produced by $\mathrm{C}_{2}$ elongation of $9,12-18: 2$ and $9,12,15-18: 3$, respectively, as follows :

$$
\begin{aligned}
9,12-18: 2 & \longrightarrow 11,14-20: 2 \longrightarrow 5,11,14-20: 3 \\
9,12,15-18: 3 \longrightarrow 11,14,17-20: 3 & \longrightarrow 5,11,14,17-20: 4
\end{aligned}
$$

It is noteworthy that the 5-desaturase in each part of $T$. cuspidata has different selectivities depending on the carbon number and number of double bonds of the substrates. It is generally known that lipids are not transported among each part of plants ${ }^{14)}$. The distinctive difference of the distribution of the NMI acids among each part of T. cuspidata supports this common idea. The first report concerning biosynthesis of 5-olefinic acids in oilseeds was presented recently. The 5-olefinic acids were formed by incubation of ${ }^{14} \mathrm{C}$-labeled substrates with the

Table-2 Fatty acid composition of the lipids from maturing seeds of $T$. cuspidata.

\begin{tabular}{l|r|r|r|r|r}
\hline \multicolumn{1}{l|}{ Date } & \multicolumn{3}{|c|}{ Sep. 22, 1979 } & Sep. 1, 1980 & Aug. 10, 1980 \\
\hline Color of fruits & Red & Yellow & Green & Green & Green \\
Lipid \% & - & 20.6 & 16.9 & 7.00 & 2.35 \\
\hline $14: 0$ & 0.04 & - & - & 0.03 & 0.43 \\
$16: 0$ & 2.53 & 2.60 & 2.71 & 2.92 & 5.71 \\
$16: 1 n-9$ & 0.01 & 0.03 & 0.01 & Tr. & 0.11 \\
$n-7$ & Tr. & 0.02 & 0.03 & Tr. & 0.06 \\
$16: 2$ & Tr. & Tr. & Tr. & Tr. & 0.21 \\
$18: 0$ & 1.41 & 1.41 & 1.54 & 1.04 & 1.13 \\
$18: 1 n-9$ & 38.12 & 37.94 & 38.08 & 33.65 & 27.17 \\
$n-7$ & Tr. & Tr. & Tr. & Tr. & Tr. \\
$18: 25,9$ & 17.74 & 17.76 & 17.08 & 17.79 & 12.24 \\
$n-6$ & 31.51 & 31.84 & 33.13 & 35.30 & 38.46 \\
$18: 35,9,12$ & 2.92 & 2.90 & 2.77 & 3.56 & 3.43 \\
$n-3$ & 1.11 & 1.24 & 1.22 & 2.11 & 5.81 \\
$18: 45,9,12,15$ & 0.17 & 0.15 & 0.24 & 0.25 & 0.46 \\
$20: 1 n-11$ & 1.45 & 1.51 & 1.40 & 1.15 & 0.96 \\
$20: 25,11$ & 0.08 & 0.09 & 0.06 & - & 0.10 \\
$n-6$ & 0.78 & 0.65 & 0.39 & 0.58 & 0.65 \\
$20: 35,11,14$ & 2.13 & 1.79 & 1.43 & 1.62 & 2.54 \\
$20: 45,11,14,17$ & - & 0.07 & Tr. & - & 0.53 \\
\hline
\end{tabular}


developing seed slices or with a cell-free ho $=$ mogenate of the seeds of medowfoam Lim = nanthes $a l b a^{15}$. Probably, T. cuspidata also contains 5-desaturase.

Fatty acid composition during the maturation of $T$. cuspidata seeds are shown in Table-2. Although the lipid contents increased remarkably as the seeds mature, the fatty acid compositions did not change, except for the earlier period of maturation having small amounts of lipids. Probably, this is due to the rapid accumulation of the acyl groups into triacylglycerols which are deposited in the seeds in inactive form. Thus, the fatty acids biosynthesized in the seeds showed nearly the same composition throughout maturation.

This work was reported at the Hokkaido Meeting of Agricultural Society of Japan, Sapporo (Dec. 1, 1979).

(Received March 19, 1982)

\section{References}

1) C.R. Smith, Jr., "Progress in Chemistry of Fats and Other Lipids", Vol. XI, Part 1, p. 137 (1970)

2) R.V. Madrigal and C.R. Smith, Jr., Lipids, 10, 502 (1975)

3) G.R. Jamieson and E.H. Reid, Phytochemistry, 11, 269 (1972)

4) Y. Koyama, Y. Okada, and Y. Toyama, Nip= pon Kagaku Zasshi, 89, 95 (1968)

5) A Sehr, M. Krohn, and Y.S. Ko, Fette, Seifen, Anstrichm., 79, 203 (1977)

6) E.G. Bligh and W.J. Dyer, Can. J. Biochem. Physiol., 37, 911 (1959)

7) Y. Itabashi and T. Takagi, Yukagaku, 29, 855 (1980)
8) R. Kleiman, G.F. Spencer, F.R. Earle, and I.A. Wolff, Lipids, 4, 135 (1969)

9) B.A. Anderson, W.W. Christie, and R.T. Holman, Lipids, 10, 215 (1975)

10) T. Takagi, J. Am. Oil Chem. Soc., 41, 516 (1964)

11) T. Takagi, C.A. Eaton, and R.G. Ackman, Can. J. Fish. Aquat. Sci., 37, 195 (1980)

12) T. Takagi and Y. Itabashi, submitted for publication in Lipids.

13) J. Bus and D.J. Frost, "Lipids" (R. Paoletti, G. Jacini, and G. Porcellati, ed.) Vol. 2, Raven Press, New York (1976) p. 343

14) P.K. Stumpf, "Lipids and Lipid Polymers in Higher Plants", (M. Tevini and H.K. Licho tenthaler ed.) Springer-Verglag, Berlin (1977) p. 77

15) M.R. Pollard and P.K. Stumpf, Plant Physiol., 66, 649 (1980).

日本産いちい種子, 仮種皮, 葉脂質中の cis-5 NMI 脂肪酸 板橋 豊・高木 徹 北海道大学水産学部 (函館市港町)

各地で採集した日本産いらい種子脂質はすべて著量の 5,9-18:2（16.0 18.4\%） と少量の 5,9,12-18:3 $(1,7 \% 3.4 \%)$ と $5,11,14-20: 3(1.0 \sim 2.8 \%)$ を cis5 NMI 脂肪酸として含有した。これと対照的に仮種皮, 葉中の中性脂質からの脂肪酸はかなりの量の $5,11,14$ $20: 3$ (葉 $8.0 \%$ ，仮種皮 $1.2 \%$ ） と $5,11,14,17-20$ : 4（葉 6.2\%，仮種皮 $1.5 \%$ ）を含有したが 5,9-18:2 は検出されたとしても微量であった。葉糖脂質からの脂 肪酸は主にリノレン酸 $(72.8 \%)$ を含有し，その他少量 の他の NMI 酸 (5, 9,12,15-18:4, 0.3\%, 5, 11, 14$20: 3,0.4 \%, 5,11,14,17-20: 41.8 \%)$ を含有した。 NMI ポリエン酸は一般に 極性脂質より中性脂質に多か った。いちい種子脂質の脂肪酸は種子の成熟の過程でほ とんど同じ組成を示した。 